\author{
Original Article
}

\title{
The Siberian pine growth dynamics in Altai Mountains, China
}

\author{
A dinâmica de crescimento do pinheiro siberiano nas montanhas de Altai, China
}

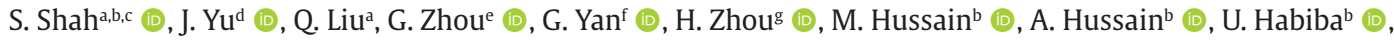

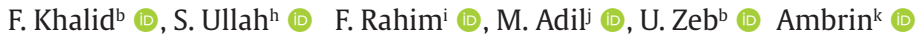

${ }^{a}$ Beijing Forestry University, College of Forestry, Beijing, China

bUniversity of Haripur, Haripur, Khyber Pakhtunkhwa, Pakistan

'Institute of Agriculture Sciences and Forestry, University of Swat. Khyber Pakhtunkhwa, Pakistan

dSchool of Landscape Architecture, Jiangsu Vocational College of Agriculture and Forestry, Jurong, Jiangsu, China

ejiangxi Academy of Forestry, Nanchang, China

fForestry Survey and Planning, Institute of Guizhou, Province Guiyang, China

gGuizhou Academy of Forestry, No. 32, Fuyuan South Road Nanming District, Guiyang, China.

hShaheed Benazir Bhutto University, Department of Forestry, Khyber Pakhtunkhwa, Pakistan

iDepartment of Botany, Bacha Khan University Charsadda, Khyber Pakhtunkhwa, Pakistan

jDepartment of Chemical and Life Sciences, Qurtaba University of Science and information technology Peshawar, Pakistan

kHadaf College, Punjab Group of Colleges, Khyber Pakhtunkhwa, Pakistan

\begin{abstract}
Climatic factors play an essential role in the growth of tree ring width. In this study, we aimed to evaluate the correlation between climatic variables and tree-ring growth characteristics of Pinus sibirica in Altai mountains, northwestern China. This study being is first of its kind on climate growth analysis of Pinus sibirica in northwestern China. The study showed great potential to understand the species growing under the specific climatic conditions. Total of 70 tree cores collected from three sites in the sampling area, out of which 63 tree cores considered for this study. The effect of climatic variables which was studied include precipitation, temperature and PDSI. Our results showed that Tree Ring Width chronology has a significantly positive correlation with the late winter (March) temperature and significant negative correlation with the July temperatures. A significant correlation was observed with the late summer precipitation whereas no significant relation found with the Palmer Drought Severity Index. These significant correlations with temperature and precipitation suggested that this tree species had the potential for the reconstruction of the past climate in the area.
\end{abstract}

Keywords: response function analysis, Siberian pine (Pinus sibirica), PDSI.

\begin{abstract}
RESUMO
Fatores climáticos desempenham papel essencial no crescimento da largura dos anéis das árvores. Neste estudo, objetivou-se avaliar a correlação entre variáveis climáticas e características de crescimento de anéis de árvores de Pinus sibirica nas montanhas de Altai, noroeste da China. Este estudo é o primeiro desse tipo na análise do crescimento climático de Pinus sibirica no noroeste da China. O estudo mostrou grande potencial para entender as espécies que crescem sob as condições climáticas específicas. Total de 70 testemunhos coletados em três locais na área de amostragem, dos quais 63 testemunhos considerados para este estudo. 0 efeito das variáveis climáticas estudadas incluem precipitação, temperatura e PDSI. Nossos resultados mostraram que a cronologia da Largura do Anel da Árvore tem uma correlação significativamente positiva com a temperatura do final do inverno (março) e uma correlação negativa significativa com as temperaturas de julho. Uma correlação significativa foi observada com a precipitação do final do verão, enquanto nenhuma relação significativa foi encontrada com o Índice de Severidade de Seca de Palmer. Essas correlações significativas com a temperatura e precipitação sugeriram que esta espécie de árvore tinha o potencial para a reconstrução do clima passado na área.
\end{abstract}

Palavras-chave: análise da função de resposta, pinho siberiano (Pinus sibirica), PDSI.

\section{Introduction}

Climatic variables including temperature and precipitation, etc. play an impactful role in the overall growth of forest trees (Fritts, 1974). Forest cover, soil type, vegetation surface, water holding capacity and rainfall interception are different factors that could affect the water availability for tree growth (Dohnal et al., 2014; Phillips

*e-mail: liuqijing@bjfu.edu.cn

Received: September 28, 2020 - Accepted: January 26, 2021 
and Ehleringer, 1995). A differing temperature of day and night, variation in moisture content between summer and winter and mountain relief promote a complex system of biomes steppe, forest, tundra, and high mountain meadows. This complex system is dependent on slope, altitude and moisture availability (Blyakharchuk et al., 2007). Tree-rings gives information about the past climate and increases our knowledge about the droughts and wet periods (Fritts, 1976). The climate growth analysis and response function had mainly been developed by applying climatic records with monthly resolution. The monthly data records are easy to calibrate as they are readily available in the form of single and gridded stations data. The instrumental records lasting for at least a century or more are hardly found in China and some parts of Russia (Beck et al., 2013; Castagneri et al., 2015; Pritzkow et al., 2016; Sanders et al., 2014; Schönbein, 2011). Several century long reconstructions developed over the recent years grown from the historical, living and subfossil ring series in past years (Büntgen et al., 2009; Cooper et al., 2013; Levanič et al., 2013; Santos et al., 2015; Seftigen et al., 2015; Wilson et al., 2013; Wilson et al., 2005; Young et al., 2015).

The Altai Mountains is considered to be among the biggest mountain system ranges in Central Asia where China, Russia, Kazakhstan and Mongolia come together and where the rivers $\mathrm{Ob}$ and Irtysh have their sources. The northwest end of the Altai Mountains is at $52^{\circ} \mathrm{N}$ and between $80^{\circ}$ and $90^{\circ} \mathrm{E}$ and extends to the south $46^{\circ} \mathrm{N}$, where the elevation decreases and merge into the high plateaus of Gobi Desert. The region covered by widespread forests dominated by different coniferous tree species, e.g., Pinus obovata, Pinus sibirica, Abies sibirica, and Larix sibirica. Pinus sibirica is one of the dominated tree species at high elevations in the Altai Mountains. The distribution of the Pinus sibirica extends to East Kazakhstan, Siberia (Russia) and Mongolia. Several tree-ring chronologies and proxy records have been developed in recent years (Briffa et al., 1995; Chen et al., 2012a; Dulamsuren et al., 2010; Frank et al., 2007; Loader et al., 2010; Myglan et al., 2008; Ovchinnikov et al., 2000; Sidorova et al., 2012). In the light of these studies, several climate-growth relationships in different regions and across environmental gradients were evaluated ( Dulamsuren et al., 2010; Frank et al., 2007). However, the Altai Mountains cover a large area, and the climate varies according to the topographic conditions. Increased seasonality and continentality are one of the few characteristics of Altai (Chen et al., 2014). The previous studies show that the summer temperature has a strong influence on the Larix sibirica growth and Picea obovata strongly correlated with late summer (August-September temperatures) in the Altai mountains (Chen et al., 2012b. The objective of the study is to find the tree response to climate after removing the size trends and the disturbance signals.

\section{Materials and Methods}

The Altai Mountains are ranging over four countries including China, Russia, Mongolia, and Kazakhstan. Most of the Altai Mountains spread over the Russian territory.
The study was carried out in the small patches of Altai mountains inside Chinese territory and for the convenience of our readers, from now onwards in this manuscript, we will use "China Altai" to describe our study area. China Altai is having an elevation range of $1573-2310 \mathrm{~m}$ asl located in the northwestern part of China, (Figure 1). The study area mainly dominated by Pinus sibirica, Abies sibirica, and Picea sibirica. It also hosts a small population of Larix sibirica and Picea obovata at some higher elevation. The species of our interest "Pinus sibirica" primarily a native species of the western Siberia has a small and sporadic population in the China Altai. The area experiences a semiarid continental climate. The mean annual temperature ranges from -2 to $-0.6{ }^{\circ} \mathrm{C}$, with coldest January of $-22{ }^{\circ} \mathrm{C}$ and July $13{ }^{\circ} \mathrm{C}$. The mean precipitation recorded was 173 $\mathrm{mm}$ to $534 \mathrm{~mm}$ most of which occur during the months of June, July and August (Figure 2). The samples were collected in the northeastern and northwestern slopes surrounding by rocky soils in subalpine meadows (Myglan et al., 2012; Sidorova et al., 2012).

Field surveys were carried out in the China Altai from (01-15 August 2017) to collect the tree core samples of Pinus sibirica. The sample sites chosen with varying elevation range. During the survey the total of 70 tree cores from Pinus sibirica were collected at breast height (1.3 $\mathrm{m}$ above ground) using increment borer. The cores were sampled in a direction parallel to the slop to avoid the influence of wood reaction. The collected cores were kept in the handmade paper straw pipe with proper coding and labeling, e.g., year, month, date, time, diameter, bark, split bark and coordinates of each tree. Single cores taken from 70 different trees and were brought to the tree ring laboratory of the College of Forestry, Beijing Forestry University (Shah et al., 2020). Tree ring samples were processed by following standard dendrochronological methods (Cook et al., 1990). The ring measurement was carried out using LINTAB ${ }^{\mathrm{TM}} 6.0$ measuring system and all the measurements are made with a precision level of $0.01 \mathrm{~mm}$ counted from the bark to the pith (Stokes and Smiley, 1968). The accuracy of the cross dating and width measurement was verified by using COFECHA (Holmes, 1983). ARSTAN software was use for standardization (Cook et al., 1990). Each sample was detrend by using the nonexponential curve to remove the non-climatic age trends (Cook and Peters, 1981). The commonly descriptive statistics used in the dendrochronology include: Standard Deviation (SD), Mean Ring Width (MRW), Mean sensitivity (MS), Autocorrelation (AC), RBAR, Signal to Noise ratio (SNR) and (EPS) expressed population signal (Liu et al., 2018). The EPS threshold value was found to be 0.85 with a running bar window of 30 years (Bunn, 2008). The chronology length shows an EPS equal to 0.85 after cut off and if an EPS more than 0.85 tells that chronology has the potential for studying response and reconstruction (Aryal et al., 2018).

The climate data (Precipitation, Temperature and Palmer Drought Severity Index) downloaded from CRUTEM4 (KNMI explorer). Three nearest meteorological stations to the study area were Habahe $(48.05 \mathrm{~N}, 86.40 \mathrm{E}, 500$ m a.s.l., 1958-2016 for temperature and 1958-1990 for precipitation); Orlovkiy Poselok (48.70N 86.48E, $1081 \mathrm{~m}$ a.s.l., Precipitation 1958-1993); and Katon Karagay (49.70N 


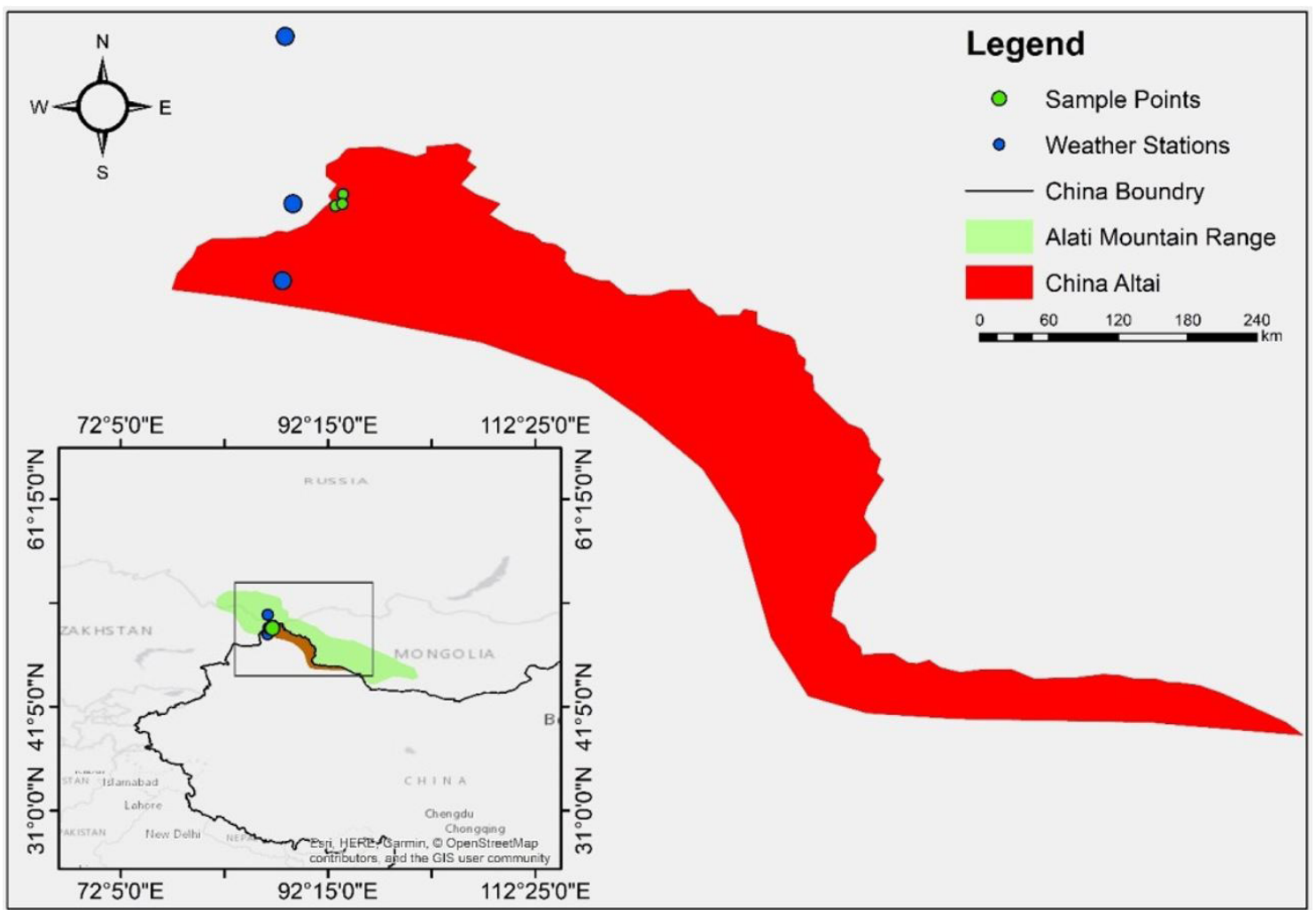

Figure 1. The map shows the Altai Mountains (light green) linked to China, Russia, Mongolia, and Kazakhstan. This mountain range extended to these three countries. The Chinese Altai represents some part of this mountain range. The Red colored part represents the Altai Mountains inside the Chinese territory.

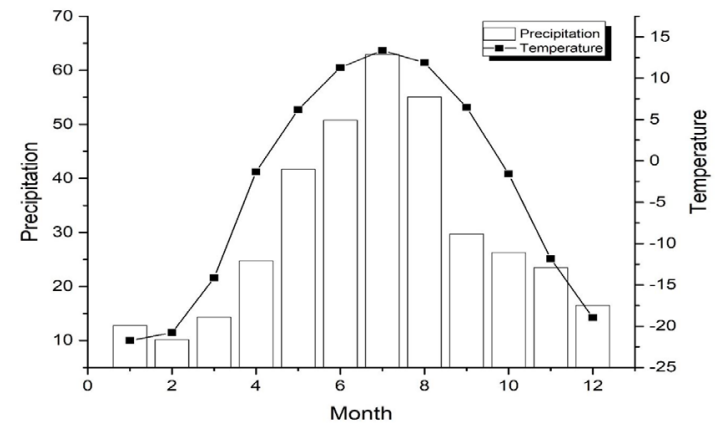

Figure 2. Regionally averaged meteorological records of Precipitation and mean Temperature throughout 1940-2015.

86.50E, $1800 \mathrm{~m}$ a.s.l.,1967-1993 for precipitation and 19402015 for temperature). After downloading the data, it was summed up and then averaged to remove the missing data. A total of 67 years temperature, precipitation and PDSI data used for climatic growth and response function analysis. After developing standardization and mean chronology, the standard chronology of the Pinus sibirica adjusted with the climatic data. The 'Treeclim' and 'bootRes' packages (Zang and Biondi, 2013, 2015) in the R Programme used for correlation and response function analysis. The Pearson's linear coefficient used for the relationship between climate and tree radial growth (Aryal et al., 2018; Miina, 2000) using DENDROCLIM 2002 program (Biondi and Waikul, 2004). A 15 months long window from previous year June to the current year September used for correlation and growth response analysis. To go deep into the standard chronology, EPS cut off analysis was performed by taking 0.85 as a threshold EPS value with a 30 year long window. The chronology divided into two different parts; one part has EPS greater than 0.85 and the second part has EPS value less than (Figure 5).

\section{Results and Discussions}

\subsection{Climatic description}

The temperature and precipitation pattern has been shown in (Figure 2). The temperature and precipitation patterns are correlated with each other as the temperature increases in March the precipitation also tends to increase and in July the temperature and precipitation reached to the maximum. In August as the temperature starts to decrease the rainfall also decreases reaching to a minimum level during November and December. The trend of maximum, minimum and mean temperatures were found to be increasing with the rate of $2.33^{\circ} \mathrm{C} /$ year, $-11.03^{\circ} \mathrm{C} /$ year and $-11.03^{\circ} \mathrm{C} /$ year respectively. Annual precipitation was found constant in the study area with the rate of $359.47 \mathrm{~mm} / \mathrm{yr}$. 


\subsection{Pinus sibirica tree-ring chronology}

The summarised results of the COFECHA given in Table 1. A total of 63 tree ring cores was measured and dated. The master series chronology length was 202 years (2017-1816) with the mean length of 138.3 years. The average interval period from the year 1913 to 2017 is 105 years. Total rings in all series were 8714 while the total dates ring checked was 8707 . Five flags were appeared in all ring width series showing cross matching problems and errors in the sampling area and within the period of tree wood. Maximum correlation was 0.734 (core 55), and the minimum correlation was 0.438 (core 7). The figure implies and indicates that the influence factors, e.g. (Stand development, Insect defoliator, and climate conditions, etc.) causing a ring too wide or narrow in one year tends to carry the effect on the following year growth. The mean series intercorrelation with the master chronology was 0.587 . Average mean sensitivity was .165 while the lowest mean sensitivity was 0.137 (core 14) and highest 0.205 (core 36). The mean of the narrow measurement rings was $0.907 \mathrm{~mm}$ and mean wider rings measurements were $1.090 \mathrm{~mm}$. Our results showed that the assessment of standard chronology has the potential to find out the relationship between climate and growth of Pinus sibirica in the study area. The pointer years in the chronology are
1831, 1848, 1864, 1880, 1894, 1901, 1968, 1994, 1996, 1999 and 2009 (Figure 3).

The chronology length in this study was 202 years long. The mean EPS and mean sensitivity were found to be (0.73) and (1.12) during the average interval period of 1913 to 2017 (105 years) found to be the shortest chronology. The standard chronology observed to be low (0.53) among three chronologies, where the mean sensitivity found to be 0.12 and EPS 0.736 presenting year to year variability of the chronology of Pinus sibirica in the Altai Mountains. Agreeing with the study conducted by (Speer, 2010), the chronology with low mean sensitivity considered not suitable for climate reconstruction.

Some previous studies carried out by (Pederson et al., 2014) on Pinus sibirica in Mongolia, it was found that EPS value $>0.85$ considered acceptable for climate reconstruction while the EPS value $<0.85$ to be not considered for climate reconstruction. The same study conducted on Pinus roxburghii but due to poor chronology statistic (Bhattacharyya et al., 1992; Bhattacharyya et al., 1988; Bhuju and Gaire, 2012; Cook et al., 2003; Wahab, 2011 ) the EPS $<0.85$ and with mean sensitivity less than 0.2 , seems that there are no reasonable agreements with the population chronology, and no useful information was established ("26th Annual North American Dendrochronological Fieldwork (NADEF, 2016).

Table 1. Pinus sibirica chronology statistics after standardization. The table showing all three-chronology resulting after standardization. The Standard chronology was considered for this study.

\begin{tabular}{cccc}
\hline \multirow{2}{*}{ Statistics } & Standard Chronology & Residual & ARSTAN \\
\cline { 3 - 4 } & & Chronology & Chronology \\
\hline Mean & .9795 & .9956 & .9687 \\
Median & .9772 & .9953 & .9623 \\
Standard deviation & .1356 & .1129 & .1475 \\
Mean sensitivity & .1034 & .1253 & .1111 \\
Skewness & .1356 & -.0745 & -.0352 \\
Kurtosis & -.0597 & 1.0232 & .1080 \\
\hline
\end{tabular}

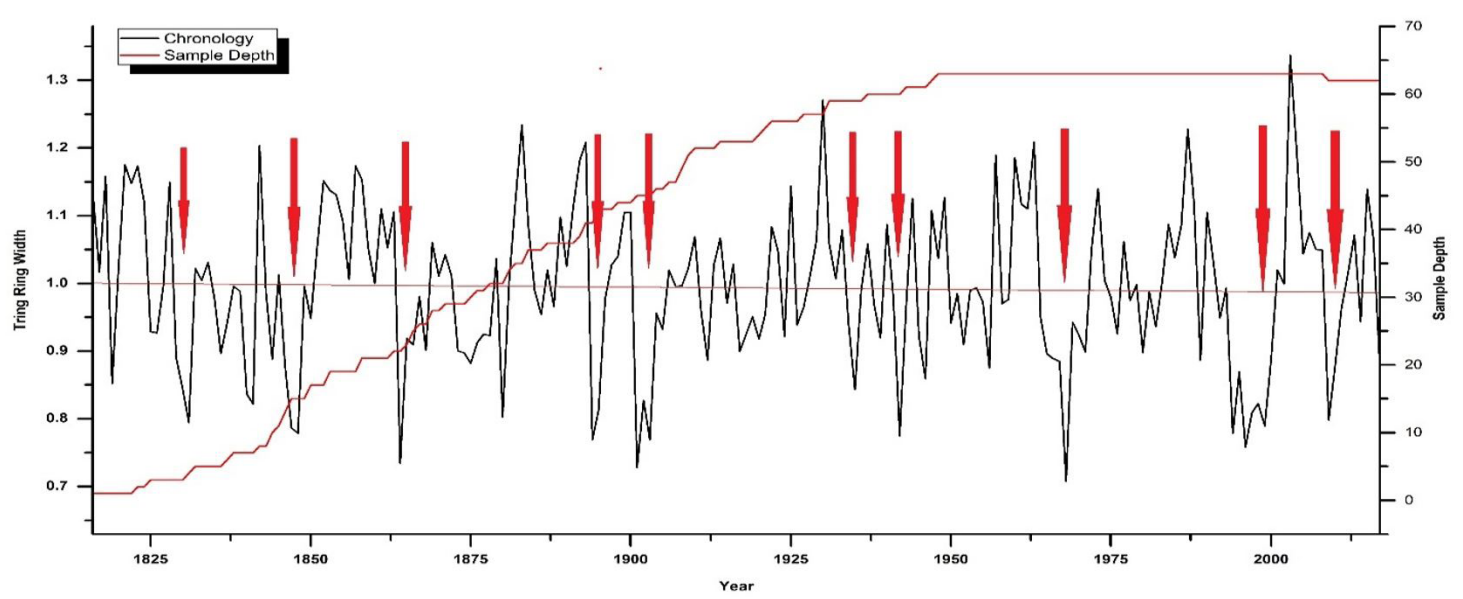

Figure 3. Showing the chronology of 202-year length of 63 sampled tree cores. The red arrows represent the pointer years. 


\subsection{Moving tree ring width- climate correlations}

We tested the temporal stability of correlations by applying 30 year moving window with a one year offset to compare the proxies. The Tree Ring Width does not show distinct changes in correlations with mean temperature and precipitation over time for 1902-2013. There was a period of negative correlation of tree ring width and previous summer temperature (June 1931-1955: June 1947-1971). Negative correlations between tree ring width and mean temperature occurred in current April (1975) till (2003) current year July (1943-1970). Some positive correlations between tree ring width and mean temperature occurred in the previous year July (1911-1951).
Some negative correlations (Figure 5) was also observed for current year August month (1902-1920). The negative correlations occurred during current year July for the period of (1911-1955), and a high negatively significant correlation occurred (1961-1988). Positive correlations occurred for the current year May precipitation (1905-1934) and some low positive correlations (Figure 4) found for February (1913-1954) and December (1966-1996).

\subsection{Response function analysis}

The response function was carried out using a sixteen-month moving window analysis starting from the previous year June to the current year September.

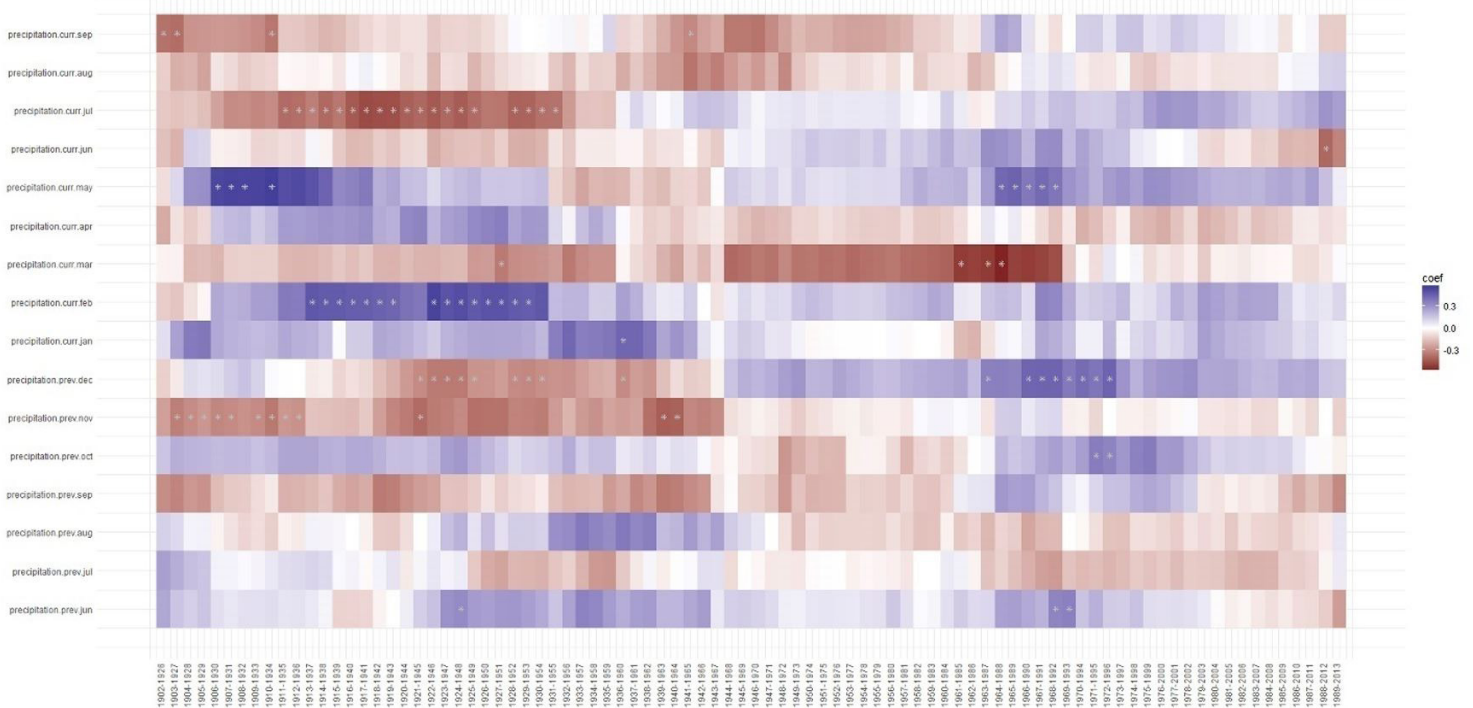

Figure 4. Tree-Ring Width chronology and Precipitation sums moving window correlations. Periods with asterisk indicate significant $(\mathrm{p}<0.05)$ correlations.

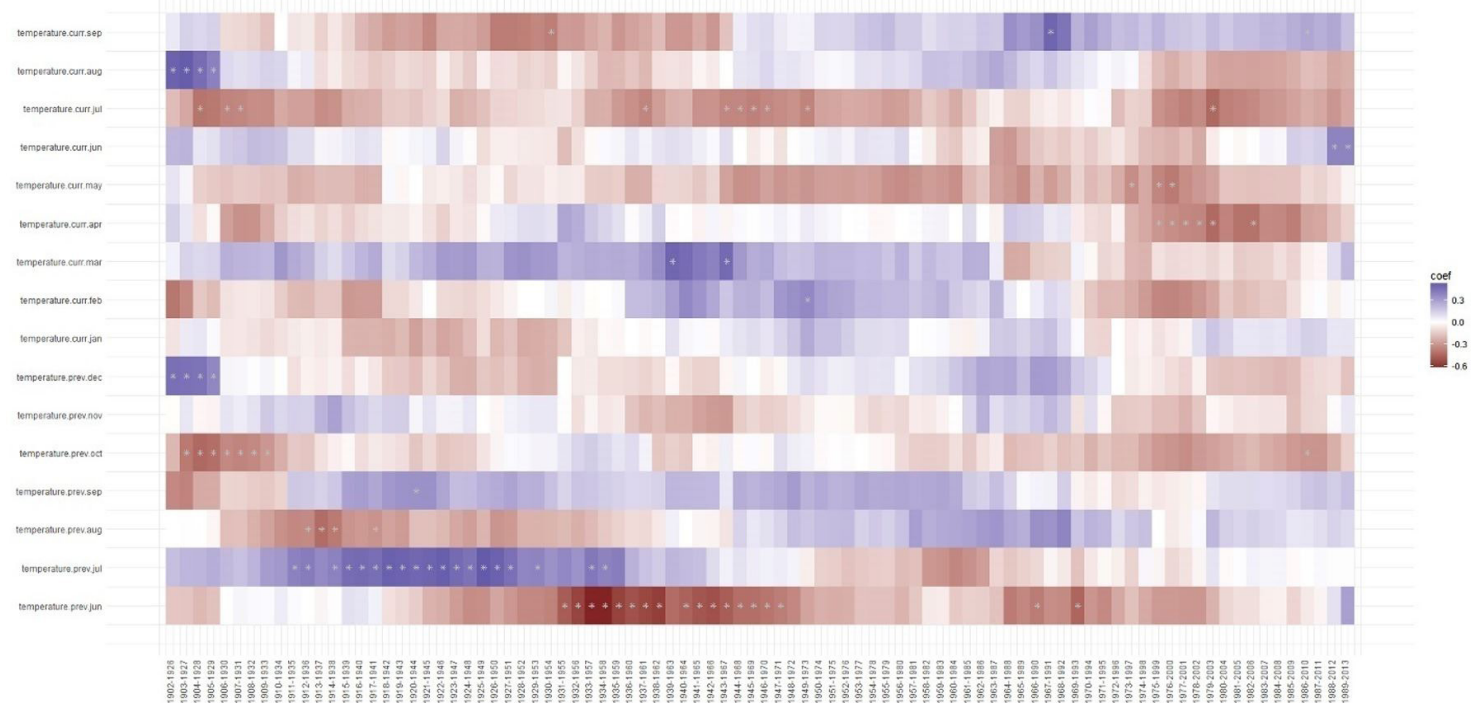

Figure 5. Tree-Ring Width chronology and mean temperature sums are moving window correlations. Periods with asterisk indicate significant $(\mathrm{p}<0.05)$ correlations. 
There was a significant positive $(0.075)$ relation between the minimum and maximum temperatures of the current year late winter (March) and a significant negative (-0.098) relation found between July temperatures with the tree ring chronology. The same significant positive correlation observed with mean temperature and tree chronology. A significant negative correlation found between the previous year's September $(-0.257)$ precipitation and a highly significant (0.005) for the current year February precipitation. There were no significant relations found between the PDSI and tree-ring chronology.

Some studies have been carried out on the dendrochronology of the Pinus sibirica in Western Siberia, Western Sayan Mountains of Russia and Northern Mongolia (D’Arrigo et al., 2001; Jacoby et al., 1996; Pederson et al., 2014; Timoshok et al., 2014). Various studies have been conducted on the past on Pinus sibirica at Russian Altai (NADEF, 2016; Taynik et al., 2016) and mixed conifers in Chinese Altay (Chen et al., 2012a, 2014) where Larix sibirica showed the same negative relationship to the July temperatures and positive correlation to the current year late winter. The other study performed on Picea obovata showed some strong mean sensitivity of 0.26 (Chen et al., 2014). Our research is not supporting the results reported by five where a positive correlation found in the previous late summer and early autumn, as our study showed a significant negative relation between precipitation and tree-ring chronology. Our results thus established the positive indirect effect of precipitation on the growth of Pinus sibirica. The rainfall during the early autumn and late summer usually promote the storage of carbohydrates in the tree which are critical for the growth of Pinus sibirica. As most of the precipitation in the Winter and early Spring received is in the form of snow, a significant positive correlation found between with late winter snowpack and its subsequent effects on soil moisture (Chen et al., 2013). The tree growth gets benefits from the previous winter and the early spring snow and precipitation resulting an increase in the soil moisture content during the initial phase of the growing season. The already existing water stress was accelerated in low elevation areas of the Altai Mountains and results in the increased May-July rainfall which can lead in a little relief of the drought. Pinus sibirica grows on thin rocky soils with low water holding capacity affecting by drought stress and low mean sensitivity to precipitation.

The growth of the Larix sibirica in the Altai Mountains mostly occurs for six months, April to September. The significant negative correlation with July temperature was due to the high temperature happening in this month at the late of growing season. Physiologically, tree rings formation consists of cell division, cell enlargement and cell wall thickening (Larson, 1967). As the rate of photosynthetic activity in plants is mostly dependent on temperature, Our results support the study of (Korner, 1999; Li et al., 2013) that high temperature of the growing season reduced the photosynthetic rate for alpine and subalpine vegetation. During late winter and early spring, the temperature showed a positive correlation with tree-ring chronology, and it's because of extreme winter experience, there is a fresh change in wet conditions and is resulting in the recharge of soil moisture benefiting trees by increasing the cambial activity during the growing season (Chen et al., 2012a). Stated in his study conducted on Siberian larch that high summer temperatures have accelerated positive correlation because warm, humid conditions of the growing season mostly lead to high radial growth. While in our study high summer temperatures are negatively responding to tree ring growth indicating that, Pinus sibirica influenced by high elevation, complex mountain terrain and spatial differences in temperatures in the Altai mountains.

\section{Conclusion}

Pinus sibirica is a conifer species inhabiting in extreme cold temperature exposed to cold winds of the continental climate. A cross-dating was so difficult and challenging because of the presence of false and missing rings. But despite all this, 202 years long chronology of Pinus sibirica was built from 1816 to 2017 AD. The chronology was statistically calculated to be promising for dendroclimatological study. The chronology of Pinus sibirica species showed a statistically positive response to late winter and early temperature while show statistically negative correlation with previous year late summer (early autumn) precipitation. Moreover, the Pinus sibirica age reaches 800 years, and our chronology consists of young species exhibiting strong responses to the temperature and precipitation. Continue work in this direction need to be carried out to understand the growth response of Pinus sibirica in the Altai Mountains under past climate variability and global warming over long spatial and temporal scales.

\section{Acknowledgements}

I am extremely thankful to Zhou Hua and Li Yuanyuan for helping me in collecting the tree ring samples. I also want to thanks Tariq Badshah for his help in measuring tree ring cores. Also, thanks to Sydney Greenfield for her help in manuscript editing.

\section{Funding}

This study is a part of Public Welfare Forest Project of China (No. 200804001).

\section{References}

ARYAL, S., BHUJU, D. R., KHARAL, D. K., GAIRE, N. P. and DYOLA, N., 2018. Climatic upshot using growth pattern of Pinus roxburghii from western Nepal. Pakistan Journal of Botany, vol. 50, no. 2, pp. 579-588.

BECK, W., SANDERS, T.G.M. and POFAHL, U., 2013. CLIMTREG: detecting temporal changes in climate-growth reactions - a computer program using intra-annual daily and yearly moving time intervals of variable width. Dendrochronologia, vol. 31, no. 3, pp. 232-241. http://dx.doi.org/10.1016/j.dendro.2013.02.003. 
BHATTACHARYYA, A., LAMARCHE JUNIOR, V.C. and HUGHES, M.K., 1992. Tree-ring chronologies from Nepal. Tree-Ring Bulletin, vol. 52, no. 1992.

BHATTACHARYYA, A., LAMARCHE JUNIOR, V.C. and TELEWSKI, F.W. 1988. Dendrochronological reconnaissance of the conifers of northwest India. Tree-Ring Bulletin, vol. 48, no. 1988.

BHUJU, D.R. and GAIRE, N.P., 2012. Plantation history and growth of old Pine stands in Kathmandu valley: a dendrochronological approach. FUUAST Journal of Biology, vol. 2, no. 2, pp. 13-17.

BIONDI, F. and WAIKUL, K., 2004. DENDROCLIM2002: A C++ program for statistical calibration of climate signals in treering chronologies. Computers \& Geosciences, vol. 30, no. 3, pp. 303-311. http://dx.doi.org/10.1016/j.cageo.2003.11.004.

BLYAKHARCHUK, T.A., WRIGHT, H.E., BORODAVKO, P.S., VAN DER KNAAP, W.O. and AMMANN, B., 2007. Late glacial and holocene vegetational history of the Altai Mountains (southwestern Tuva Republic, Siberia). Palaeogeography, Palaeoclimatology, Palaeoecology, vol. 245, no. 3-4, pp. 518-534. http://dx.doi. org/10.1016/j.palaeo.2006.09.010.

BRIFFA, K.R., JONES, P.D., SCHWEINGRUBER, F.H., SHIYATOV, S.G. and COOK, E.R., 1995. Unusual twentieth-century summer warmth in a 1,000-year temperature record from Siberia. Nature, vol. 376, no. 6536, pp. 156-159. http://dx.doi.org/10.1038/376156a0.

BUNN, A.G., 2008. A dendrochronology program library in R(dplR). Dendrochronologia, vol. 26, no. 2, pp. 115-124. http://dx.doi. org/10.1016/j.dendro.2008.01.002.

BÜNTGEN, U., FRANK, D., CARRER, M., URBINATI, C. and ESPER, J. 2009. Improving Alpine summer temperature reconstructions by increasing sample size. Trace, vol. 7, pp. 36-43.

CASTAGNERI, D., PETIT, G. and CARRER, M., 2015. Divergent climate response on hydraulic-related xylem anatomical traits of Picea abies along a 900-m altitudinal gradient. Tree Physiology, vol. 35, no. 12, pp. 1378-1387. http://dx.doi.org/10.1093/treephys/ tpv085. PMid:26377871.

CHEN, F., YUAN, Y., CHEN, F.-H., WEI, W., YU, S., CHEN, X., FAN, Z., ZHANG, R., ZHANG, T., SHANG, H. and QIN, L., 2013. A 426-year drought history for Western Tian Shan, Central Asia, inferred from tree rings and linkages to the North Atlantic and IndoWest Pacific Oceans. The Holocene, vol. 23, no. 8, pp. 1095-1104. http://dx.doi.org/10.1177/0959683613483614.

CHEN, F., YUAN, Y., WEI, W., FAN, Z., ZHANG, T., SHANG, H., ZHANG, R., YU, S., JI, C. and QIN, L., 2012a. Climatic response of ring width and maximum latewood density of Larix sibirica in the Altay Mountains, reveals recent warming trends. Annals of Forest Science, vol. 69, no. 6, pp. 723-733. http://dx.doi.org/10.1007/ s13595-012-0187-2.

CHEN, F., YUAN, Y., WEI, W., WANG, L., YU, S., ZHANG, R., FAN, Z. SHANG, H., ZHANG, T. and LI, Y., 2012b. Tree ring density-based summer temperature reconstruction for Zajsan Lake area, East Kazakhstan. International Journal of Climatology, vol. 32, no. 7, pp. 1089-1097. http://dx.doi.org/10.1002/joc.2327.

CHEN, F., YUAN, Y.-J., WEI, W.-S., ZHANG, T.-W., SHANG, H.-M. and ZHANG, R., 2014. Precipitation reconstruction for the southern Altay Mountains (China) from tree rings of Siberian spruce, reveals recent wetting trend. Dendrochronologia, vol. 32, no. 3, pp. 266-272. http://dx.doi.org/10.1016/j.dendro.2014.06.003.

COOK, E., BRIFFA, K., SHIYATOV, S., MAZEPA, V. and JONES, P., 1990. Data analysis. In: E.R. Cook and L.A. Kairiukstis, eds. Methods of dendrochronology. Dordrecht: Springer, pp. 97162. http://dx.doi.org/10.1007/978-94-015-7879-0_3.

COOK, E.R. and PETERS, K. 1981. The smoothing spline: a new approach to standardizing forest interior tree-ring width series for dendroclimatic studies. Tree-Ring Bulletin, vol. 41, no. 1981.
COOK, E.R., KRUSIC, P.J. and JONES, P.D., 2003. Dendroclimatic signals in long tree-ring chronologies from the Himalayas of Nepal. International Journal of Climatology: A Journal of the Royal Meteorological Society, vol. 23, no. 7, pp. 707-732. http:// dx.doi.org/10.1002/joc.911.

COOPER, R.J., MELVIN, T.M., TYERS, I., WILSON, R.J.S. and BRIFFA, K.R., 2013. A tree-ring reconstruction of East Anglian (UK) hydroclimate variability over the last millennium. Climate Dynamics, vol. 40, pp. 1019-1039. http://dx.doi.org/10.1007/ s00382-012-1328-x.

D'ARRIGO, R., JACOBY, G., FRANK, D., PEDERSON, N., COOK, E., BUCKLEY, B., NACHIN, B., MIJIDDORJ, R. and DUGARJAV, C., 2001. 1738 years of monoglian temperature variability inferred from a tree-ring width chronology of Siberian Pine. Geophysical Research Letters, vol. 28, no. 3, pp. 543-546. http://dx.doi. org/10.1029/2000GL011845.

DOHNAL, M., ČERNÝ, T., VOTRUBOVÁ, J. and TESAŘ, M., 2014. Rainfall interception and spatial variability of throughfall in spruce stand. Journal of Hydrology and Hydromechanics, vol. 62, no. 4, pp. 277-284. http://dx.doi.org/10.2478/johh-2014-0037.

DULAMSUREN, C., HAUCK, M., KHISHIGJARGAL, M., LEUSCHNER, H.H. and LEUSCHNER, C., 2010. Diverging climate trends in Mongolian taiga forests influence growth and regeneration of Larix sibirica. Oecologia, vol. 163, no. 4, pp. 1091-1102. http:// dx.doi.org/10.1007/s00442-010-1689-y. PMid:20571829.

FRANK, D., OVCHINNIKOV, D., KIRDYANOV, A. and ESPER, J., 2007. The potential for long-term climatic reconstructions in the Central Altay Mountains from living and relict larch. Trace, vol. 5, pp. 85-96.

FRITTS, H.C. 1976. Tree rings and climate. London: Academic Press.

FRITTS, H.C., 1974. Relationships of ring widths in arid-site conifers to variations in monthly temperature and precipitation. Ecological Monographs, vol. 44, no. 4, pp. 411-440. http://dx.doi. org/10.2307/1942448.

HOLMES, R.L., 1983. Computer-assisted quality control in tree-ring dating and measurement. Tree-Ring Bulletin, vol. 43, no. 1983.

JACOBY, C.G., D’ARRIGO, R. D. and DAVAAJAMTS, T., 1996. Mongolian Tree Rings and 20th-Century Warming. Science in China Series E: Technological Sciences, vol. 273, no. 5276, pp. 3.

KÖRNER, C., 1999. Alpine plant life. 2nd ed. Berlin: Springer. http:// dx.doi.org/10.1007/978-3-642-98018-3.

LARSON, P.R., 1967. Effects of temperature on the growth and wood formation of ten Pinus resinosa sources. Silvae Genetica, vol. 16, pp. 58-65.

LEVANIČ, T., POPA, I., POLJANŠEK, S. and NECHITA, C., 2013. A 323year long reconstruction of drought for SW Romania based on black pine (Pinus Nigra) tree-ring widths. International Journal of Biometeorology, vol. 57, no. 5, pp. 703-714. http://dx.doi. org/10.1007/s00484-012-0596-9. PMid:23053066.

LI, X., LIANG, E., GRIČAR, J., PRISLAN, P., ROSSI, S. and ČUFAR, K., 2013. Age dependence of xylogenesis and its climatic sensitivity in Smith fir on the south-eastern Tibetan Plateau. Tree Physiology, vol. 33, no. 1, pp. 48-56. http://dx.doi.org/10.1093/treephys/ tps113. PMid:23185065.

LIU, B., LIANG, E., LIU, K. and CAMARERO, J.J., 2018. Species-and elevation-dependent growth responses to climate warming of mountain forests in the Qinling Mountains, Central China. Forests, vol. 9, no. 5, pp. 248. http://dx.doi.org/10.3390/f9050248.

LOADER, N., HELLE, G., LOS, S.O., LEHMKUHL, F. and SCHLESER, G.H., 2010. Twentieth-century summer temperature variability in the southern Altai Mountains: a carbon and oxygen isotope study of tree-rings. The Holocene, vol. 20, no. 7, pp. 1149-1156. http://dx.doi.org/10.1177/0959683610369507. 
MIINA, J., 2000. Dependence of tree-ring, earlywood and latewood indices of Scots pine and Norway spruce on climatic factors in eastern Finland. Ecological Modelling, vol. 132, no. 3, pp. 259-273. http://dx.doi.org/10.1016/S0304-3800(00)00296-9.

MYGLAN, V., OIDUPAA, O.C., KIRDYANOV, A. and VAGANOV, E., 2008. 1929-year tree-ring chronology for the Altai-Sayan region (Western Tuva). Archaeology, Ethnology \& Anthropology of Eurasia, vol. 36, no. 4, pp. 25-31. http://dx.doi.org/10.1016/j. aeae.2009.03.003.

MYGLAN, V.S., OIDUPAA, O.C. and VAGANOV, E.A., 2012. A 2367-year tree-ring chronology for the Altai-Sayan region (Mongun-Taiga Mountain Massif). Archaeology, Ethnology \& Anthropology of Eurasia, vol. 40, no. 3, pp. 76-83. http://dx.doi.org/10.1016/j. aeae.2012.11.009.

NORTH AMERICAN DENDROCHRONOLOGICAL FIELDWORK - NADEF, 2016. Pack Forest, Eatonville, WA.

OVCHINNIKOV, D., ADAMENKO, M. and PANUSHKINA, I., 2000. 1105year tree-ring chronology in Altai region and its application for reconstruction of summer temperature. Geolines, vol. 11, pp. 121-122.

PEDERSON, N., HESSL, A.E., BAATARBILEG, N., ANCHUKAITIS, K.J. and DI COSMO, N., 2014. Pluvials, droughts, the Mongol Empire, and modern Mongolia. Proceedings of the National Academy of Sciences of the United States of America, vol. 111, no. 12, pp. 4375-4379. http://dx.doi.org/10.1073/pnas.1318677111. PMid:24616521.

PHILLIPS, S.L. and EHLERINGER, J.R., 1995. Limited uptake of summer precipitation by bigtooth maple (Acer grandidentatum Nutt) and Gambel's oak (Quereus gambelii Nutt). Trees, vol. 9, no. 4, pp. 214-219. http://dx.doi.org/10.1007/BF00195275.

PRITZKOW, C., WAZNY, T., HEUSSNER, K.U., SŁOWIŃSKI, M., BIEBER, A., LIÑÁN, I.D., HELLE, G. and HEINRICH, I., 2016. Minimum winter temperature reconstruction from average earlywood vessel area of European oak (Quercus robur) in N-Poland. Palaeogeography, Palaeoclimatology, Palaeoecology, vol. 449, pp. 520-530. http://dx.doi.org/10.1016/j.palaeo.2016.02.046.

SANDERS, T., PITMAN, R. and BROADMEADOW, M., 2014. Speciesspecific climate response of oaks (Quercus spp.) under identical environmental conditions. iForest - Biogeosciences and Forestry, vol. 7, no. 2, pp.61-69. http://dx.doi.org/10.3832/ifor0911-007.

SANTOS, J.A., CARNEIRO, M.F., ALCOFORADO, M.J., LEAL, S., LUZ, A.L., CAMUFFO, D. and ZORITA, E., 2015. Calibration and multi-source consistency analysis of reconstructed precipitation series in Portugal since the early 17th century. The Holocene, vol. 25, no. 4, pp. 663-676. http://dx.doi.org/10.1177/0959683614566250.

SCHÖNBEIN, J., 2011. Zur Rekonstruktion von Hochwasserereignissen in Europa aus holzanatomischen Parametern und historischen Quellen. Freiburg: Albert-Ludwigs-Universität. Masters Dissertation.

SEFTIGEN, K., BJÖRKLUND, J., COOK, E.R. and LINDERHOLM, H.W., 2015. A tree-ring field reconstruction of Fennoscandian summer hydroclimate variability for the last millennium. Climate Dynamics, vol. 44, pp. 3141-3154. http://dx.doi.org/10.1007/ s00382-014-2191-8.
SHAH, S., YU, J., LIU, Q., SHI, J., AHMAD, A., KHAN, D. and MANNAN, A., 2020. Climate growth response of Pinus sibirica (Siberian pine) in the Altai mountains, northwestern China. Pakistan Journal of Botany, vol. 52, no. 2, pp. 593-600. http://dx.doi. org/10.30848/PJB2020-2(16)

SIDOROVA, O.V., SAURER, M., MYGLAN, V.S., EICHLER, A., SCHWIKOWSKI, M., KIRDYANOV, A.V., BRYUKHANOVA, M.V., GERASIMOVA, O.V., KALUGIN, I.A., DARYIN, A.V. and SIEGWOLF, R.T.W., 2012. A multi-proxy approach for revealing recent climatic changes in the Russian Altai. Climate Dynamics, vol. 38, no. $1-2$, pp. $175-188$. http://dx.doi.org/10.1007/s00382010-0989-6.

SPEER, J.H., 2010. Fundamentals of tree-ring research. Tucson: University of Arizona Press.

STOKES, M. A., \& SMILEY, T. L., 1968. An introduction to tree-ring dating. Tucson: University of Arizona Press.

TAYNIK, A.V., BARINOV, V.V., OIDUPAA, O.C., MYGLAN, V.S., REINIG, F. and BÜNTGEN, U., 2016. Growth coherency and climate sensitivity of Larix sibirica at the upper treeline in the Russian Altai-Sayan Mountains. Dendrochronologia, vol. 39, pp. 10-16. http://dx.doi.org/10.1016/j.dendro.2015.12.003.

TIMOSHOK, E.E., TIMOSHOK, E.N. and SKOROKHODOV, S.N., 2014. Ecology of Siberian stone pine (Pinus sibirica Du Tour) and Siberian larch (Larix sibirica Ledeb.) in the Altai mountain glacial basins. Russian Journal of Ecology, vol. 45, no. 3, pp. 194-200. http://dx.doi.org/10.1134/S1067413614030138.

WAHAB, M., 2011. Population dynamics and dendrochronological potential of pine tree species from district Dir. Pakistan: Federal Urdu University of Arts, Science and Technology. PhD thesis of Department of Botany.

WILSON, R., MILES, D., LOADER, N.J., MELVIN, T., CUNNINGHAM, L., COOPER, R. and BRIFFA, K., 2013. A millennial long March-July precipitation reconstruction for southern-central England. Climate Dynamics, vol. 40, pp. 997-1017. http://dx.doi. org/10.1007/s00382-012-1318-z.

WILSON, R.J., LUCKMAN, B.H. and ESPER, J., 2005. A 500 year dendroclimatic reconstruction of spring-summer precipitation from the lower Bavarian Forest region, Germany. International Journal of Climatology, vol. 25, no. 5, pp. 611-630. http://dx.doi. org/10.1002/joc.1150.

YOUNG, G.H.F., LOADER, N.J., MCCARROLL, D., BALE, R.J., DEMMLER, J.C., MILES, D., NAYLING, N.T., RINNE, K.T., ROBERTSON, I., WATTS, C. and WHITNEY, M., 2015. Oxygen stable isotope ratios from British oak tree-rings provide a strong and consistent record of past changes in summer rainfall. Climate Dynamics, vol. 45, pp. 3609-3622. http://dx.doi.org/10.1007/s00382-015-2559-4.

ZANG, C. and BIONDI, F., 2013. Dendroclimatic calibration in R: the bootRes package for response and correlation function analysis. Dendrochronologia, vol. 31, no. 1, pp. 68-74. http:// dx.doi.org/10.1016/j.dendro.2012.08.001.

ZANG, C. and BIONDI, F., 2015. Treeclim: an R package for the numerical calibration of proxy-climate relationships. Ecography, vol. 38, no. 4, pp. 431-436. http://dx.doi.org/10.1111/ecog.01335. 